\section{How Sodium Chloride Concentration in the Nutrient Solution Influences the Mineral Composition of Tomato Leaves and Fruits}

\author{
Francesco Giuffrida, Marianna Martorana, and Cherubino Leonardi ${ }^{1}$ \\ Department of Horticulture and Food Technology, University of Catania, \\ Via Valdisavoia 5, 95123 Catania, Italy
}

Additional index words. Solanum lycopersicum, electrical conductivity, organ age, organ position, nutrient composition

\begin{abstract}
Tomato plants (Solanum lycopersicum L. cv. Durinta) were grown in an open soilless system to evaluate the effects of sodium chloride $(\mathrm{NaCl})$ concentration in the nutrient solution on the ion compositions in plant tissues. The treatments were defined by a factorial combination of five $\mathrm{NaCl}$ concentrations and three leaves position/age and two fruits' position. Seedlings were transplanted in perlite and, 7 days after transplanting, five salinity treatments were imposed by adding 7, 21, 37, 49, or $64 \mathrm{~mm}$ of $\mathrm{NaCl}$ to the nutrient solutions; the final electrical conductivities were: $2.7,4.5,6.0,7.5$, and $8.6 \mathrm{dS} \cdot \mathrm{m}^{-1}$, respectively. Increased salinity in the nutrient solution resulted in a reduction in tomato dry matter (from 534 to $375 \mathrm{~g}$ per plant) and in a linear increase in sodium (from $0.37 \%$ to $1.39 \%$ ) and chloride (from $1.75 \%$ to $5.73 \%$ ) in the leaves as well as in the fruit tissues (from $0.08 \%$ to $0.26 \%$ for sodium and from $0.63 \%$ to $1.34 \%$ for chloride). Leaf under the first cluster showed higher levels of sodium $(+54 \%)$ and chloride $(+32 \%)$ than leaf under the fifth cluster and old leaf accumulated more sodium $(+15 \%)$ and chloride $(+25 \%)$ than younger ones. The exposure of the tomato plants to increasing salinity resulted in a linear decline in nitrate (from $1.21 \%$ to $0.50 \%$ ), total nitrogen (from $3.31 \%$ to $3.03 \%$ ), sulphate (from $3.71 \%$ to $3.12 \%$ ), and potassium leaves (from $2.76 \%$ to $1.51 \%$ ); the potassium reduction was more evident in younger leaves than in older ones. All macronutrients, except calcium, decreased in the fruit tissues with increasing $\mathrm{NaCl}$ concentration in the nutrient solution. However, for phosphate, the reduction of the ion concentration was evident only in the fruit from the fifth cluster $(-35 \%)$. The position of the fruit on the plant significantly affected the concentration of ion, which was higher for all determined ions in the fruit of the first truss. The levels of $\mathrm{Na}^{+}$and $\mathrm{Cl}^{-}$found in the plant tissue seem to confirm the hypothesis that the plant dry biomass reduction may also be traced to the toxicity of these ions as a consequence of this high concentration. On the other hand, although generally influenced by antagonism with sodium and chloride, the amount of main macronutrients did not reach deficiency levels that influenced the growth processes, except in the case of potassium.
\end{abstract}

High salt concentration in irrigation water is common in coastal areas where intensive production systems are located.

The increase of salinity in the rhizosphere produces an increase in the osmotic pressure of the nutrient solution, which leads to water stress (Rodriguez et al., 1997). Additionally, a high uptake of $\mathrm{Na}^{+}$and $\mathrm{Cl}^{-}$, which is common in these conditions, can reduce the functionality of the photosynthetic apparatus (Flowers et al., 1977). These negative effects are more pronounced in the lesser compartmentation of $\mathrm{Na}^{+}$and $\mathrm{Cl}^{-}$in the old leaves than in the young ones (Shannon et al., 1987). Moreover, other negative effects are the

Received for publication 22 Jan. 2009. Accepted for publication 31 Mar. 2009.

This work was supported by the Italian Ministry of University and Research (MIUR-PRIN 2005 Coordinator Prof. Garibaldi).

${ }^{1}$ To whom reprint requests should be addressed; e-mail cherubino.leonardi@unict.it.
However, a suboptimal concentration of nutrients in the mature leaves can be considered less detrimental considering their low photosynthetic efficiency (Tichá et al., 1985).

It appears evident that among the effects that sodium chloride has on tomato, there are some related to the accumulation of the two ions and to the antagonism to the nutrients. Nevertheless, the information available in the literature shows that the effects of these mechanisms on the mineral composition of plant tissues are not consistent (Cuartero and Fernández-Muñoz, 1999). Additionally, there is a lack of information about the different organographic portions as related to their position on the plant and their age.

Starting from these considerations, the aim of the current study was to assess whether an increased sodium chloride $(\mathrm{NaCl})$ concentration of the nutrient solution: 1) raises sodium and/or chloride to toxic levels in tomato plants; 2) influences the leaf nutritional status, thus determining a nutrient deficiency; and 3 ) modifies the ion concentration in the fruit. The possible interactions between $\mathrm{NaCl}$ in the nutrient solution and the position and/ or age of the organs were also evaluated.

\section{Materials and Methods}

Location, plant material, and growth conditions. The experiment was conducted in Spring-Summer 2006 in an $800-\mathrm{m}^{2}$ unheated polyethylene greenhouse situated on the Experimental Farm of Catania University in southern Italy (long. $37.3^{\circ} \mathrm{N}$, lat. $15.0^{\circ} \mathrm{E} ; 20$ $\mathrm{m}$ a.s.1.). The tomato (Solanum lycopersicum L.) hybrid Durinta $F_{1}$ (Western Seed S.A., Naaldwijk, NL) was selected as one of the most representative varieties cultivated in Italy because of its high crop performance, fruit quality, and the high demand for truss tomatoes in national and international markets. Seeds were germinated in peat on 23 Feb. 2006. The seedlings were transplanted $30 \mathrm{~d}$ after sowing (25 Mar.), at the third trueleaf stage, one for each pot (height $20 \mathrm{~cm}$, width $19 \mathrm{~cm}$ ) containing $5 \mathrm{~L}$ of perlite (particle size 3 to $5 \mathrm{~mm}$ ). The pots were placed on troughs with $33 \mathrm{~cm}$ between pots and $100 \mathrm{~cm}$ between troughs, creating a plant density of 3 plants per $\mathrm{m}^{2}$. Plants were topped above the seventh truss and the last harvest was carried out at the end of July.

Plants were grown under natural light conditions; ventilation was provided automatically when the air temperature exceeded $25{ }^{\circ} \mathrm{C}$. The mean air temperature, the vapor pressure deficit, and the global radiation inside the greenhouse during the experimental period were recorded on a data logger (CR10 $\mathrm{X}$; Campbell Scientific Ltd., Loughborough, $\mathrm{UK}$ ) and saved in a personal computer.

The treatments were defined by a factorial combination of five $\mathrm{NaCl}$ concentrations in the nutrient solution and the position/age of the organs considered.

Nutrient solution management. The tomato plants were exposed to five salinity treatments obtained by adding $7,21,37,49$, or $64 \mathrm{~mm}$ $\mathrm{NaCl}$ to the nutrient solutions giving an 
electrical conductivity of $2.7,4.5,6.0,7.5$, or $8.6 \mathrm{dS} \cdot \mathrm{m}^{-1}$, respectively. The first concentration of $\mathrm{NaCl}$ is considered optimal for irrigation water in Mediterranean conditions. The basic nutrient solutions had the following composition: $10.5 \mathrm{~mm} \mathrm{~N}-\mathrm{NO}_{3}{ }^{-}, 1.5 \mathrm{~mm}$ $\mathrm{H}_{2} \mathrm{PO}_{4}^{-}, 6.5 \mathrm{~mm} \mathrm{~K}^{+}, 1.2 \mathrm{~mm} \mathrm{SO}_{4}^{2-}, 3.0 \mathrm{~mm}$ $\mathrm{Ca}^{2+}, 1.0 \mathrm{mM} \mathrm{Mg}^{2+}, 15 \mu \mathrm{M} \mathrm{Fe}^{3+}, 10 \mu \mathrm{M} \mathrm{Mn}^{2+}$, $0.75 \mu \mathrm{M} \mathrm{Cu}^{2+}, 5 \mu \mathrm{M} \mathrm{Zn}^{2+}, 30 \mu \mathrm{M} \mathrm{B}^{3+}$, and $0.5 \mu \mathrm{M} \mathrm{Mo}^{6+}$. The $\mathrm{pH}$ of the nutrient solution for all treatments was 5.9. All nutrient solutions were prepared using demineralized water. Plants were irrigated with a basic nutrient solution for $7 \mathrm{~d}$ before being subjected to different saline treatments; the fixed $\mathrm{NaCl}$ concentrations were gradually reached over a period of $5 \mathrm{~d}$.

The nutrient solution was pumped from independent tanks through an open drip irrigation system with one emitter per plant and a flow rate of $4 \mathrm{~L} \cdot \mathrm{h}^{-1}$. The frequency of irrigation and the volume of the nutrient solution were scheduled on the basis of the water release curve of the substrate, solar radiation at the crop level (measured using a pyranometer), and plant size. The integral of solar radiation, by which an irrigation event was triggered, was quantified by gravimetrically measuring the plant consumption of the water contained in the substrate at intervals of $-10 \mathrm{hPa}$ to $-25 \mathrm{hPa}$ of matric potential. Additionally, the volume of irrigation water was adjusted to ensure a leaching fraction sufficient to contain the increase of salt in the substrate (Kempkes and Stanghellini, 2003).

Data collection and analysis. To quantify the assimilation capacity of the plant, the biomass obtained from its epigeous organs (stem, leaves, and fruits) was taken from the crop at the successive interventions of pruning, harvesting, and sampling at the end of the cycle. The biomass was dried in a forced-air oven $\left(70^{\circ} \mathrm{C}\right)$ until steady weight was achieved.

The following plant organs were sampled during the trial:

Leaf under the first [77 d after transplanting (DAT)] and fifth (99 DAT) cluster at the turning of the third fruit (Leaf I and Leaf $V$, respectively);

Leaf under the fifth cluster (121 DAT) at the end of the crop cycle (Old leaf V); and Fruit from the first (84 DAT) and fifth (111 DAT) cluster at the ripening of the third fruit (Fruit I and Fruit V, respectively).

First and fifth trusses were chosen to evaluate the influence of climatic conditions and sink/source relations on crop response to $\mathrm{NaCl}$ stress.

The concentration of reduced nitrogen in leaf and fruit tissues was determined after mineralization with sulfuric acid using the "Kjeldahl method," whereas the content of the main inorganic ions $\left(\mathrm{NO}_{3}{ }^{-}, \mathrm{H}_{2} \mathrm{PO}_{4}^{-}, \mathrm{K}^{+}\right.$, $\left.\mathrm{SO}_{4}{ }^{2-}, \mathrm{Ca}^{2+}, \mathrm{Mg}^{2+}, \mathrm{Na}^{+}, \mathrm{Cl}^{-}\right)$was determined by means of ionic chromatography (Dionex IC 25 Ion Chromatograph, 40 EG Eluent Generator; Dionex Corporation, Sunnyvale, CA) using an Ion Pac AS11-HC separation

Table 1. Duration and average climate conditions recorded during differentiation sampling interval. ${ }^{\mathrm{z}}$

\begin{tabular}{lccccc}
\hline & $\begin{array}{c}\text { Duration } \\
(\text { days })\end{array}$ & $\begin{array}{c}\text { Vapor pressure } \\
\text { deficit }(\mathrm{kPa})\end{array}$ & $\begin{array}{c}\text { Relative } \\
\text { humidity }(\%)\end{array}$ & $\begin{array}{c}\text { Temperature } \\
\left({ }^{\circ} \mathrm{C}\right)\end{array}$ & $\begin{array}{c}\text { Radiation } \\
\left(\mathrm{MJ} \cdot \mathrm{m}^{-2} \cdot \mathrm{d}^{-1}\right)\end{array}$ \\
\hline Leaf I & 60 & 0.9 & 64.5 & 20.9 & 13.8 \\
Leaf V & 50 & 1.3 & 60.7 & 24.8 & 13.9 \\
Old leaf V & 60 & 1.5 & 58.3 & 26.9 & 14.2 \\
Fruit I & 58 & 1.0 & 63.8 & 22.1 & 14.1 \\
Fruit V & 49 & 1.5 & 59.6 & 26.6 & 14.2 \\
\hline
\end{tabular}

"I" and "V" indicate the position of the considered plant organ expressed as truss number.

column for the anions and an Ion Pac CS-12A for the cations. The extraction of the ions was carried out using the method described by Elia and Santamaria (1995), using ultrapure water for the anions.

Statistical analysis. The experiment was conducted as a randomized complete block design with four replicates; each experimental unit consisted of 12 plants. A two-way fixed-effects general linear model analysis of variance (ANOVA) was used to determine the effects of salinity and the position/age of the organs on the concentration of ions in the leaves and fruit. Organ position and age were considered together; when the interaction was significant, the data were presented in separate curves to show any differences in the trend. For position/age as the main factor, when significant differences were found, a Student-Newman-Keuls post hoc multiple comparison procedure was used to assess significant differences between individual means. Analyses were conducted on nontransformed data. ANOVA was performed for each ion based on replicates. Simple regression models were adopted to determine the linear and quadratic relationships between $\mathrm{NaCl}$ and each ion. For each one, the simplest significant regression is reported and discussed. An $\alpha$ level of 0.05 was selected for the ANOVA and Student-Newman-Keuls post hoc tests Statistical analyses were performed with CoStat release 6.311 (CoHort Software, Monterey, CA).

\section{Results}

Climatic conditions inside the greenhouse. To better understand the effects caused by the addition of $\mathrm{NaCl}$ to the nutrient solution, it should be highlighted that the interval between appearance and sampling of the different organs changed depending on the average climatic conditions throughout the growing period (Table 1). The organs from the first truss grew over a longer period $(+18 \%)$ than those of the fifth one as a result of the lower air mean temperature (20.9 versus $24.9^{\circ} \mathrm{C}$ ) recorded during the growing interval.

Biomass production and partitioning. The increase of the $\mathrm{NaCl}$ concentration in the nutrient solution had clear effects on assimilation shown by a reduction of up to $30 \%$ in dry matter in the epigeous organs of the plant (Fig. 1). Partitioning of the assimilates between the vegetative and reproductive portions was not significantly affected (data not shown).

Sodium and chloride concentration in leaf and fruit. The increase in the $\mathrm{NaCl}$ concen- tration in the nutrient solution caused a linear increase in sodium and chloride in the leaves as well as in the fruit tissues (Tables 2 and 3 ). However, significant differences were recorded depending on the organ and its age or position. Leaf I showed a higher level of $\mathrm{Na}^{+}$and $\mathrm{Cl}^{-}$than Leaf $\mathrm{V}$ (Table 2) and for sodium, this difference was more pronounced with increased salinity (from $0.58 \%$ to $2 \%$ in Leaf I and from $0.27 \%$ to $1.6 \%$ in Leaf V) (Fig. 2). Older leaves accumulated more $\mathrm{Na}^{+}$ $(+16 \%)$ and $\mathrm{Cl}^{-}(+25 \%)$ than younger leaves (Table 2). Regarding fruit position, the basal fruit had $0.20 \% \mathrm{Na}^{+}$and $1.12 \% \mathrm{Cl}^{-}$, which were, respectively, $42 \%$ and $27 \%$, higher than Fruit V (Table 3). Although sodium and chloride increased in the plant organs as $\mathrm{NaCl}$ increased in the nutrient solution, the ratio between these ions varied according to the position of the leaves as well as the fruit. Compared with sodium, the accumulation of chloride was twofold in Leaf I and threefold in Leaf V, regardless of their age (Fig. 3). The slope of the linear regression of Leaf I differs significantly $(P=0.05)$ from that of Leaf $\mathrm{V}$ and old leaf V. A similar result was also observed for the fruit (Table 3).

Concentration of macronutrients in leaf and fruit. The exposure of tomato plants to increasing amounts of $\mathrm{NaCl}$ resulted in a linear decline in concentration of total nitrogen, nitrate, sulphate, and potassium in leaves; whereas the position and/or the age of the leaves significantly influenced the content of all macronutrients except phosphate (Table 2). A significant interaction was observed for nitrogen and potassium in leaves in which the pattern of reduction was not similar. Both total (Fig. 2) and reduced nitrogen in Leaf V

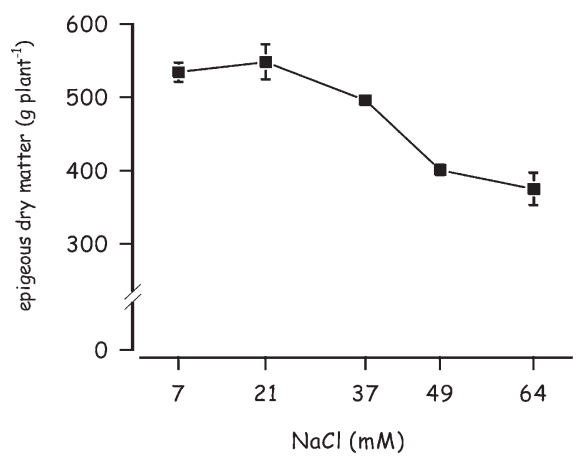

Fig. 1. Effect of sodium chloride concentration in the nutrient solution on epigeous dry matter production in tomato (in this and in the following figures, vertical bars indicate \pm SE of the mean; $\mathrm{n}=4$; their absence indicates that the size was less than the symbol). 
Table 2. Mean effects of sodium chloride concentration in the nutrient solution and leaf position/age on mineral composition of tomato leaves (percent on dry weight basis). ${ }^{\mathrm{z}}$

\begin{tabular}{|c|c|c|c|c|c|c|c|c|c|c|c|}
\hline $\mathrm{NaCl}(\mathrm{mm})$ & Position/age & $\mathrm{Na}^{+}$ & $\mathrm{Cl}^{-}$ & $\mathrm{N}$ & Reduced N & $\mathrm{NO}_{3}^{-}$ & $\mathrm{H}_{2} \mathrm{PO}_{4}^{-}$ & $\mathrm{SO}_{4}^{2-}$ & $\mathrm{K}^{+}$ & $\mathrm{Ca}^{2+}$ & $\mathrm{Mg}^{2+}$ \\
\hline 7 & & 0.37 & 1.75 & 3.31 & 3.04 & 1.21 & 1.45 & 3.71 & 2.76 & 4.83 & 1.04 \\
\hline 37 & & 1.03 & 3.63 & 3.17 & 3.01 & 0.68 & 1.44 & 2.93 & 2.02 & 4.71 & 1.06 \\
\hline 49 & & 1.27 & 4.90 & 3.04 & 2.91 & 0.59 & 1.50 & 3.11 & 1.72 & 4.63 & 1.03 \\
\hline \multirow{3}{*}{64} & Leaf I & $1.42 \mathrm{a}$ & $4.49 \mathrm{a}$ & $2.59 \mathrm{~b}$ & $2.31 \mathrm{~b}$ & $1.22 \mathrm{a}$ & 1.48 & $3.79 \mathrm{a}$ & $1.61 \mathrm{c}$ & $6.00 \mathrm{a}$ & $1.60 \mathrm{a}$ \\
\hline & Leaf V & $0.65 \mathrm{c}$ & $3.02 \mathrm{c}$ & $3.46 \mathrm{a}$ & $3.29 \mathrm{a}$ & $0.74 \mathrm{~b}$ & 1.48 & $3.19 \mathrm{~b}$ & $2.47 \mathrm{a}$ & $4.34 \mathrm{~b}$ & $0.81 \mathrm{~b}$ \\
\hline & Old leaf V & $0.75 \mathrm{~b}$ & $3.78 \mathrm{~b}$ & $3.36 \mathrm{a}$ & $3.26 \mathrm{a}$ & $0.45 \mathrm{c}$ & 1.50 & $2.84 \mathrm{~b}$ & $2.17 \mathrm{~b}$ & $3.97 \mathrm{c}$ & $0.76 \mathrm{~b}$ \\
\hline Position/age & & $* * *$ & $* *$ & $* * *$ & $* * *$ & $* * *$ & NS & $* * *$ & $* * *$ & $* * *$ & $* * *$ \\
\hline Interaction $^{\mathrm{x}}$ & & $* * *$ & NS & * & * & NS & NS & NS & $* * *$ & NS & * \\
\hline
\end{tabular}

z"I" and "V" indicate the position of the considered plant organ expressed as truss number.

${ }^{\mathrm{y}} \mathrm{L}=$ linear regression; $\mathrm{NS}=$ nonsignificant; *, ${ }^{* *}$, and *** represent significance at $0.01<P<0.05,0.001<P<0.01$, and $P<0.001$, respectively. In each column, values followed by different letters differ significantly at $P=0.05$ (Student-Newman-Keuls).

${ }^{\mathrm{x}}$ Data concerning significant interactions are presented separately.

Table 3. Mean effects of sodium chloride concentration in the nutrient solution and fruit position on mineral composition of tomato fruits (percent on dry weight basis). ${ }^{z}$

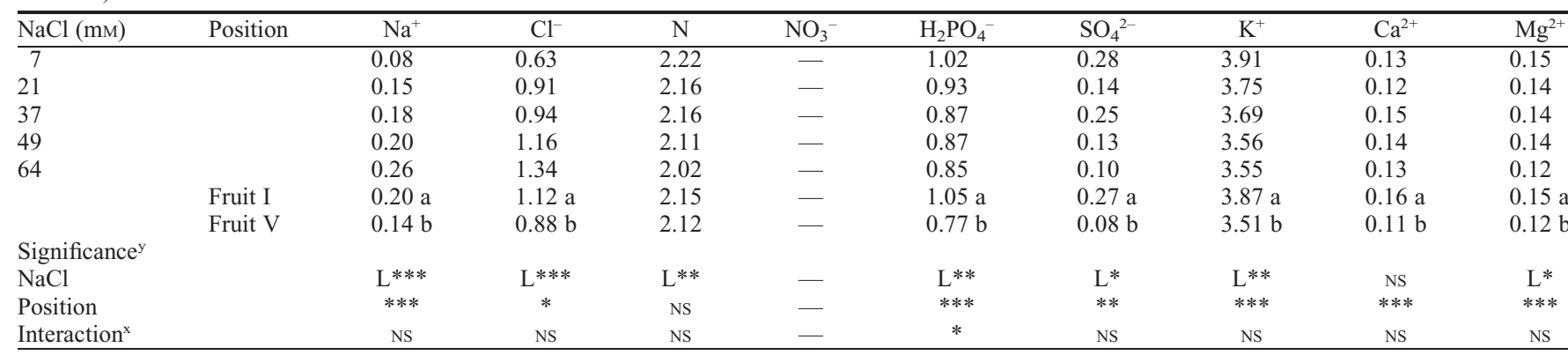

"I" and "V" indicate the position of the considered plant organ expressed as truss number.

${ }^{\mathrm{y}} \mathrm{L}=$ linear regression; $\mathrm{NS}=$ nonsignificant; ${ }^{*},{ }^{* *}$, and $* * *$ represent significance at $0.01<P<0.05,0.001<P<0.01$, and $P<0.001$, respectively. In each column, values followed by different letters differ significantly at $P=0.05$ (Student-Newman-Keuls).

${ }^{x}$ Data concerning significant interactions are presented separately.
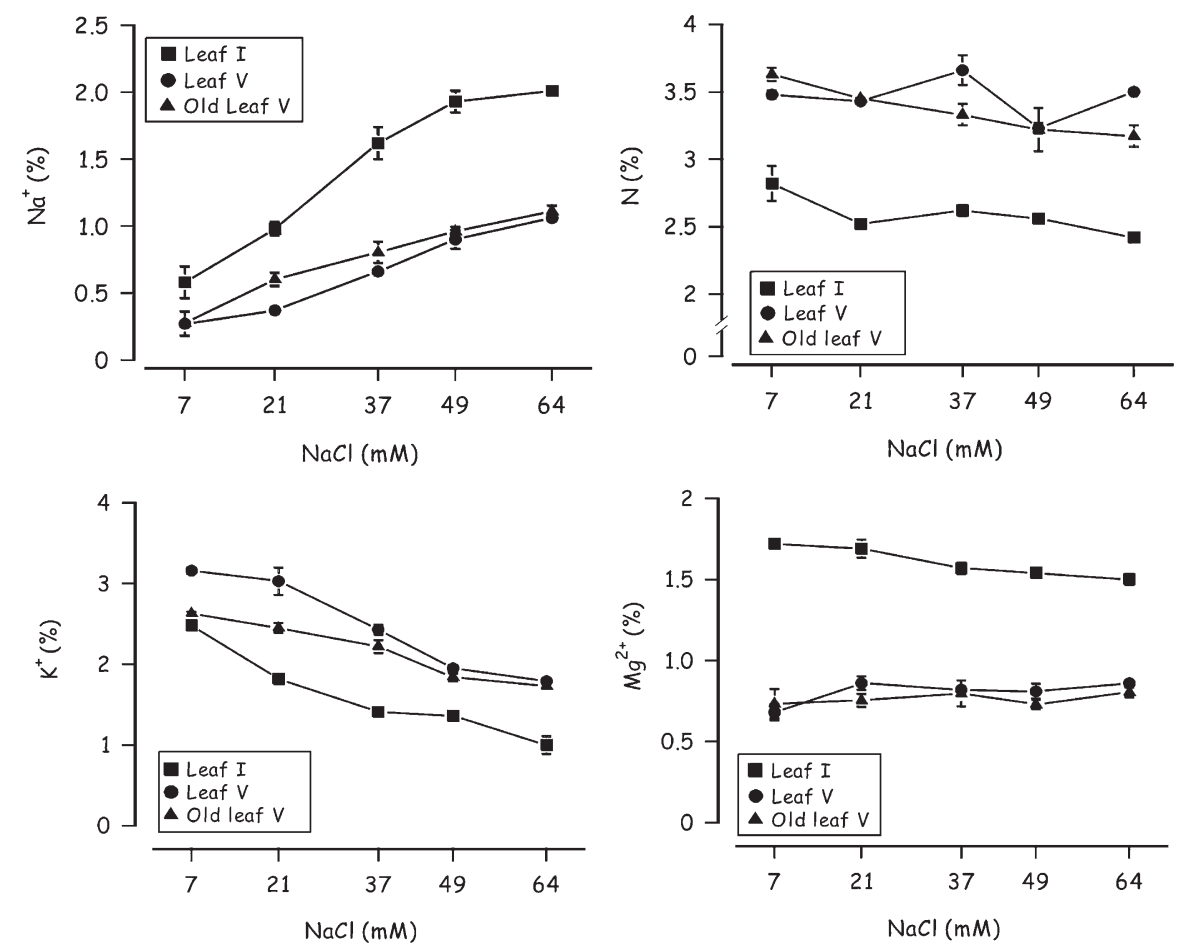

Fig. 2. Concentrations of ions (mean $\pm \mathrm{SE}$ ) in different leaves in relation to sodium chloride concentration in the nutrient solution. (data not shown) showed no clear variation, but a significant reduction in the older leaves (from $3.63 \%$ to $3.17 \%$ for total nitrogen) was recorded. In contrast, the reduction in potassium was more evident in young Leaf V $(-44 \%$ and $-35 \%$, respectively, for Leaf $\mathrm{V}$ and old leaf V) (Fig. 2). The trend in Leaf I was similar to that observed in Leaf $\mathrm{V}$, although the concentration of $\mathrm{K}^{+}$was always lower in Leaf I and reached $1 \%$ in conditions of high salinity.

With increased salinity, the concentration of $\mathrm{Mg}^{2+}$ changed in relation to the position of the leaves. Leaf I was characterized by lower ion content under saline conditions $(-13 \%)$ and Leaf $\mathrm{V}$ by higher ion content $(+26 \%)$ (Fig. 2).

Similarly, the increase of salinity in the nutrient solution caused a linear decrease in total nitrogen, phosphate, sulphate, potassium, and magnesium in the fruit (Table 3 ). However, a significant interaction was observed for phosphate with a decreasing of the ion concentration $(-42 \%)$ only in Fruit V (Fig. 4). Fruit position significantly affected fruit ion levels, which were always higher in the fruit of the first truss.

\section{Discussion}

Biomass production and partitioning. The effect of salinity on dry matter production and its influence on the partitioning of assimilates between the leaves and fruit of tomato 


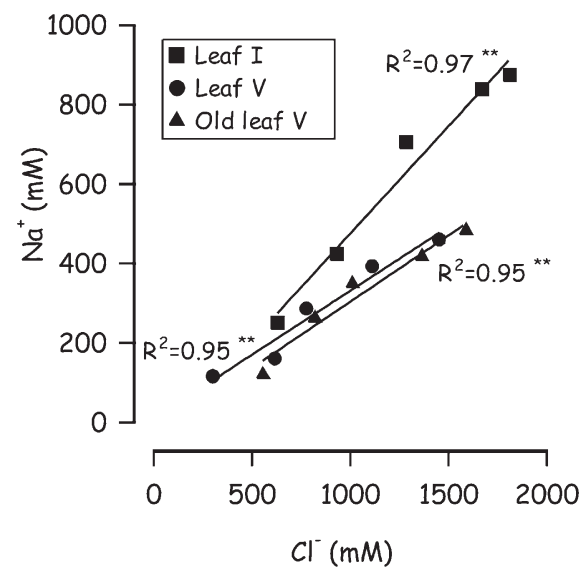

Fig. 3. Relationships between sodium and chloride concentrations in different leaves. The linear regressions are $\mathrm{y}=0.54 \mathrm{x}-65.2$ for Leaf $\mathrm{I}, \mathrm{y}=$ $0.32 x+9.15$ for Leaf $V$, and $y=0.33 x-30.13$ for old leaf V. Double asterisks (**) indicate that the linear regressions are significant for $0.001<P<0.01$

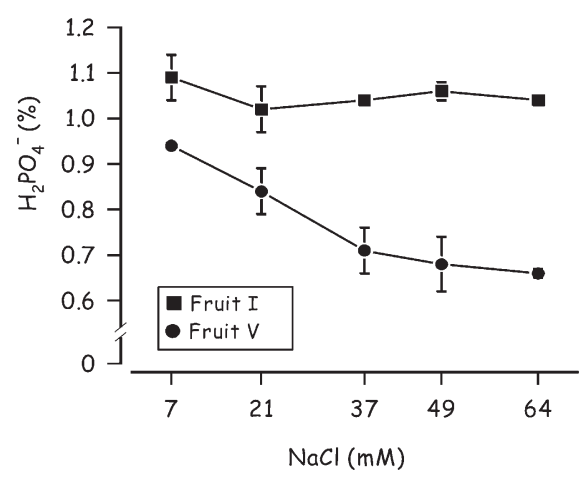

Fig. 4. Phosphate concentration (mean \pm SE) in different fruits in relation to sodium chloride concentration in the nutrient solution.

has been well documented (Mavrogianopoulos et al., 2002). The harmful effects of $\mathrm{NaCl}$ salinity have been traced to the alteration of the water balance resulting from the osmotic potential of the nutrient solution (Erdei and Taleisnik, 1993) to a disturbance in metabolism caused by high $\mathrm{Na}^{+}$and $\mathrm{Cl}^{-}$concentrations in plant tissues (Greenway and Munns, 1980) and to the inhibition of the absorption of nutrients by plant roots (Greenway and Munns, 1980). Therefore, the low biomass yield under salinity obtained in this study confirmed the observations made by the previously stated authors in their independent studies.

Sodium and chloride concentration in leaf and fruit. The increasing $\mathrm{NaCl}$ concentration of the nutrient solution determined a remarkable accumulation of $\mathrm{Na}^{+}$and $\mathrm{Cl}^{-}$in tomato leaves and fruits (Cuartero and FernándezMuñoz, 1999) as well as in other vegetable (Colla et al., 2006; Rouphael et al., 2006) and floricultural crops (Carter and Grieve, 2008). The greater aptitude of basal leaves to accumulate sodium, as a result of increasing the level of $\mathrm{NaCl}$ in the root environment, could be related to water transpired by the leaves because $\mathrm{Na}^{+}$is transported to shoots in the transpiration stream in the xylem (Munns and Tester, 2008; Tester and Davenport, 2003). Contrary to the results for $\mathrm{Na}^{+}$, we did not find an interaction between leaf position and salinity to explain $\mathrm{Cl}^{-}$uptake. This is because of the different transport mechanisms of ions and the patterns of accumulation and/or partitioning (White and Broadley, 2001).

The higher $\mathrm{Na}^{+}$and $\mathrm{Cl}^{-}$levels in the basal leaf (Leaf I) may also be the result of the longer period of exposure to salinity than the upper leaf (Leaf V) as reported by del Amor et al. (2001). This hypothesis is also confirmed by the greater level of the two ions in old leaves as compared with young ones (Leaf V) and agreed with Soliman and Doss's (1992) observations; the old leaves transpired for a longer time and this could influence accumulation. Besides, the older leaves acted as tissue for the accumulation of excess ions, maintaining low concentrations in the younger tissue (Munns and Tester, 2008). However, according to our results, the similar trend of ion in leaves of different ages, increasing salinity in the nutrient solution, did not confirm the hypothesis of Maggio et al. (2007) concerning possible mechanisms aimed at preserving the photosynthetic apparatus of younger leaves above a certain salinity threshold.

Unlike that which has been reported by Satti et al. (1994) for sodium and Sonneveld and Van Der Burg (1991) for chloride, the levels in the fruit of both clusters were less than those found in the leaves, suggesting that only the leaves acted as accumulation organs. Concerning the position of the fruit, the higher content of $\mathrm{Na}^{+}$and $\mathrm{Cl}^{-}$on the basal truss can be explained, like in the case of the leaves, by the longer period of exposure to salinity (del Amor et al., 2001).

Concentration of macronutrients in leaf and fruit. Regarding the effect of the presence of $\mathrm{NaCl}$ in the nutrient solution on the level of nutrients in the plant tissues, the slight reduction in total nitrogen found in the leaves could be related to a reduced $\mathrm{NO}_{3}{ }^{-}$ uptake resulting from competition with $\mathrm{Cl}^{-}$ (Papadopoulos and Rending, 1983). However, in salinity conditions, the absorption of $\mathrm{NO}_{3}^{-}$may be more closely linked to reduced water absorption rather than to antagonism with $\mathrm{Cl}^{-}$(Abdelgadir et al., 2005). The pattern of total and reduced nitrogen in leaves of different ages is in line with the results of Mavrogianopoulos et al. (2002), who found a clear reduction only in the leaves that had been under stress for a longer period. The observed effect of salinity on the level of nitrogen $(\mathrm{N})$ in leaves cannot be considered particularly important because the $\mathrm{N}$ concentration in all treatments was within the sufficiency range (Jones et al., 1991).

The absence of any clear effect of $\mathrm{NaCl}$ salinity on the leaf phosphate concentration is consistent with previous results on tomato (Mavrogianopoulos et al., 2002) and other vegetable crop (Kawasaky et al., 1983; Savvas and Lenz, 1996). In contrast to the leaves, we found a significant reduction of the ion concentration in the fruit when $\mathrm{NaCl}$ was increased in the nutrient solution. This is probably related to the lower amount of phosphate that reaches the stressed fruit as a result of the equal influx concentration at different levels of salinity (Magán et al., 2005) and the lower water influx (Xu et al., 1995). This effect was more pronounced for the fruit of the fifth truss; at this stage, the flux of water to the fruit is more highly affected by competition between a greater number of transpiring organs; thus, the aforementioned effect was more significant.

Very little attention has been paid to the influence of salinity on sulfur uptake and accumulation in crops. In our research, the leaf content of $\mathrm{SO}_{4}{ }^{2-}$ decreased as salinity increased up to $37 \mathrm{~mm}$ of $\mathrm{NaCl}$; similar results have been observed by FernándezGarcía et al. (2004) for grafted tomato plants. The reduction in sulphate leaves and fruit seems to be related to $\mathrm{Cl}^{-}$salinity, which enhances the accumulation of sulfur in the roots (Mor and Manchanda, 1992).

Numerous studies on tomato as well as other crops have shown that the $\mathrm{K}^{+}$concentration in plant tissue is reduced as $\mathrm{Na}^{+}$in the root media increases (Carvajal et al., 1999; del Amor et al., 2001). The mechanism involved may be related to the competition between sodium and potassium for the site of absorption on the plasmalemma (Mills et al., 1985) and to the $\mathrm{K}^{+}$uptake through highly selective pathways, whereas $\mathrm{Na}^{+}$ appears to move through less selective systems (Maathuis and Amtmann, 1999). The $\mathrm{K}^{+}$decrease observed at increasing levels of salinity was more evident in Leaves $\mathrm{V}$ than in the old leaves in relation to the reduction in water uptake, which was higher in young leaves than in old ones. Data obtained by $\mathrm{Hu}$ and Schmidhalter (1997) on wheat show that, although salinity causes a decrease in the accumulation of $\mathrm{K}^{+}$in the leaves, if an optimal level of potassium fertilization was adopted, no deficiency of the element is observed. Such results do not concur with ours, because we worked under optimal potassium availability; however, all the leaves reached potassium concentrations considered to be deficient (Hochmuth et al., 2004).

Reduction of potassium in the fruits, as a result of the increase of salinity in the nutrient solution, has to be considered because of the role that potassium plays on the quality of the berries. Numerous studies have indeed evidenced a positive correlation between potassium and titratable acidity (Petersen et al., 1998), the level of carotenoids, and, in particular, of lycopene (Fanasca et al., 2006), and a negative correlation between potassium in fruit and physiological disorders like blotchy ripening (Winsor and Massey, 1958).

The $\mathrm{Ca}^{2+}$ uptake did not clearly compete with that of $\mathrm{Na}^{+}$in the root environment as indicated by the leaf and fruit concentration of $\mathrm{Ca}^{2+}$ and as previously reported by other investigators (Carvajal et al., 1999). This is because the $\mathrm{Ca}^{2+}$ variation in saline conditions is profoundly influenced by environmental 
factors (Scaife and Clarkson, 1978) and transpiration (Xu et al., 1995).

Increases in salinity are not always associated with reductions in leaf $\mathrm{Mg}^{2+}$ concentration (Carvajal et al., 1999; del Amor, et al., 2001). The different patterns shown by Leaf $\mathrm{I}$ and $\mathrm{V}$ are consistent with the fact that $\mathrm{Mg}^{2+}$ is a phloem mobile nutrient (Bukovac and Wittwer, 1957). Although many studies have analyzed the $\mathrm{Mg}^{2+}$ content in vegetative plant tissues in relation to salinity, few have considered the $\mathrm{Mg}^{2+}$ level in fruits. The decrease of the $\mathrm{Mg}^{2+}$ concentration in fruit resulting from the increase of salinity is in agreement with the findings of del Amor et al. (2001).

\section{Conclusion}

The levels of $\mathrm{Na}^{+}$and $\mathrm{Cl}^{-}$found in the plant tissues confirmed the hypothesis that plant dry biomass reduction may also be traced to the toxicity of these ions as a consequence of their high concentrations. On the other hand, although generally influenced by antagonism with $\mathrm{Na}^{+}$and $\mathrm{Cl}^{-}$, the amount of main macronutrients did not reach deficiency levels that influenced the growth processes, except in the case of potassium.

\section{Literature Cited}

Abdelgadir, E.M., M. Okam, and H. Fujiyama. 2005. Characteristics of nitrate uptake by plants under salinity. J. Plant Nutr. 28:33-46.

Awad, A.S., D.G. Edwards, and L.C. Campbell. 1990. Phosphorus enhancement of salt tolerance of tomato. Crop Sci. 30:123-128.

Bukovac, M.C. and S.H. Wittwer. 1957. Absorption and mobility of foliar applied nutrients. Plant Physiol. 32:428-435.

Carter, C.T. and C.M. Grieve. 2008. Mineral nutrition, growth, and germination of Antirrhinum majus L. (Snapdragon) when produced under increasingly saline conditions. HortScience 43:710-718.

Carvajal, M., V. Martinez, and A. Cerdá. 1999. Influence of magnesium and salinity on tomato plants grown in hydroponic culture. J. Plant Nutr. 22:177-190

Colla, G., Y. Rouphael, M. Cardarelli, D. Massa, A. Salerno, and E. Rea. 2006. Yield, fruit quality and mineral composition of grafted melon plants grown under saline conditions. J. Hort. Sci. Biotechnol. 81:146-152.

Cuartero, J. and R. Fernández-Muñoz. 1999. Tomato and salinity. Sci. Hort. 78:83-125.

del Amor, F.M., V. Martinez, and A. Cerdá. 2001. Salt tolerance of tomato plants as affected by stages of plant development. HortScience 36:1260-1263.

Elia, A. and P. Santamaria. 1995. Effetti della forma azotata sul peperone (Capsium annuum L.). II. N., ossalati e contenuto dei principali anioni inorganici. Riv. di Agron. 29:234-241.

Erdei, L. and E. Taleisnik. 1993. Changes in water relation parameters under osmotic and salt stresses in maize and sorghum. Physiol. Plant. $89: 381-387$

Fanasca, S., G. Colla, G. Maiani, E. Venneria, Y. Rouphael, E. Azzini, and F. Saccardo. 2006. Changes in antioxidant content of tomato fruits in response to cultivar and nutrient solution composition. J. Agr. Food Chem. 54:43194325 .

Fernández-García, N., V. Martínez, and M. Carvajal. 2004. Effect of salinity on growth, mineral composition, and water relations of grafted tomato plants. J. Plant Nutr. Soil Sci. 167: 616-622.

Flagella, Z., V. Cantore, M.M. Giuliani, E. Tarantino, and A. De Caro. 2002. Crop salt tolerance: Physiological, yield and quality aspects. Recent Res. Devel. Plant Biol. 2:155-186.

Flowers, T.J., P.F. Troke, and A.R. Yeo. 1977. The mechanism of salt tolerance in halophytes. Annu. Rev. Plant Physiol. 31:149-190.

Greenway, H. and R. Munns. 1980. Mechanism of salt tolerance in nonhalophytes. Annu. Rev. Plant Physiol. 31:149-190.

Hale, M.G. and D.M. Orcutt. 1987. Nutrient stress, p. 71-92. In: Orcutt, D.M. and M.G. Hale (eds.). The physiology of plants under stress. John Wiley \& Sons, Inc, New York, NY.

Ho, L.C., R. Belda, M. Brawn, J. Andrews, and P. Adams. 1993. Uptake and transport of calcium and the possible causes of blossom-and-rot in tomato. J. Expt. Bot. 44:509-518.

Hochmuth, G., D. Maynard, C. Vavrina, E. Hanlon, and E. Simonne. 2004. Plant tissue analysis and interpretation for vegetable crops in Florida. Florida Cooperative Extension Service, Institute of Food and Agricultural Sciences, University of Florida, document HS964.

$\mathrm{Hu}, \mathrm{Y}$. and U. Schmidhalter. 1997. Interactive effects of salinity and macronutrient level on wheat. 2. Composition. J. Plant Nutr. 20:11691182 .

Jones, J.B., B. Wolf, and H.A. Mills. 1991. Plant analysis handbook. A practical sampling, preparation, analysis, and interpretation guide. Micro Macro Publishing, Athens, GA.

Kawasaky, T., T. Akiba, and M. Moritsugu. 1983. Effects of high concentrations of sodium chloride and polyethylene glycol on the growth and ion absorption in plants. I. Water culture experiment in a greenhouse. Plant Soil 75:7585

Kempkes, F. and C. Stanghellini. 2003. Modelling salt accumulation in a closed system: A tool for management with irrigation water of poor quality. Acta Hort. 641:143-148.

Maathuis, F.J.M. and A. Amtmann. 1999. K nutrition and $\mathrm{Na}^{+}$toxicity: The basis of cellular $\mathrm{K}^{+} / \mathrm{Na}^{+}$ratios. Ann. Bot. (Lond.) 84:123-133.

Magán, J.J., E. Casas, M. Gallardo, R.B. Thompson, and P. Lorenzo. 2005. Uptake concentrations of a tomato crop in different salinity conditions. Acta Hort. 697:365-369.

Maggio, A., G. Raimondi, A. Martino, and S. De Pascale. 2007. Salt stress response in tomato beyond the salinity tolerance threshold. Environ. Exp. Bot. 59:276-282.

Mavrogianopoulos, G., D. Savvas, and V. Vogli. 2002. Influence of $\mathrm{NaCl}$-salinity imposed on half of the root system of hydroponically grown tomato on growth, yield, and tissue mineral composition. J. Hort. Sci. Biotechnol. 77:557564.

Mills, D., K. Robinson, and T.K. Hodges. 1985. Sodium and potassium fluxes and compartmentation in roots of Atriplex and oat. Plant Physiol. 78:500-509.

Mor, R.P. and H.R. Manchanda. 1992. Influence of phosphorus on the tolerance of table pea to chloride and sulphate salinity in a sandy soil. Arid Soil Res. Rehabil. 6:41-52.

Munns, R. and M. Tester. 2008. Mechanisms of salinity tolerance. Annu. Rev. Plant Biol. 59: 651-681.

Papadopoulos, I. and V.V. Rending. 1983. Interactive effects of salinity and nitrogen on growth and yields of tomato plants. Plant Soil 73:4757.

Petersen, K.K., J. Willumsen, and K. Kaack. 1998. Composition and taste of tomatoes as affected by increased salinity and different salinity sources. J. Hort. Sci. Biotechnol. 73:205215.

Rodriguez, P., J. Dell'Amico, D. Morales, M.J.S. Sanchez Blanco, and J.J. Alarcon. 1997 Effects of salinity on growth, shoot water relation and root hydraulic conductivity in tomato plants. J. Agr. Sci. 128:439-444.

Rouphael, Y., M. Cardarelli, E. Rea, A. Battistelli, and G. Colla. 2006. Comparison of the subirrigation and drip-irrigation system for greenhouse zucchini squash production using saline and non-saline nutrient solutions. Agr. Water Manage. 82:99-117.

Satti, S.M.E., A.A. Ibrahim, and S.M. Al-Kindi. 1994. Enhancement of salinity tolerance in tomato: implications of potassium and calcium in flowering and yield. Commun. Soil Sci. Plant Anal. 25:2825-2840.

Savvas, D. and F. Lenz. 1996. Influence of $\mathrm{NaCl}$ concentration in the nutrient solution on mineral composition of eggplants grown in sand culture. J. App. Bot. 70:124-127.

Scaife, A. and D.T. Clarkson. 1978. Calciumrelated disorders in plants-An explanation for the effects of weather. Plant Soil 50:723725 .

Shannon, M.C., J.W. Gronwald, and M. Tal. 1987. Effect of salinity on growth and accumulation of organic and inorganic ions in cultivated and wild tomatoes species. J. Amer. Soc. Hort. Sci. 112:416-423.

Soliman, M.S. and M. Doss. 1992. Salinity and mineral nutrition effects on growth and accumulation of organic and inorganic ions in two cultivated tomato varieties. J. Plant Nutr. 15:2789-2790.

Sonneveld, C. and A.M.M. Van Der Burg. 1991. Sodium chloride salinity in fruit vegetable crops in soilless culture. Neth. J. Agr. Sci. 39 $115-122$

Tester, M. and R. Davenport. 2003. $\mathrm{Na}^{+}$tolerance and $\mathrm{Na}^{+}$transport in higher plants. Ann. Bot. (Lond.) 91:503-527.

Tichá, I., F. Čatský, D. Hodáňová, F. Pospíšilová, M. Kaše, and Z. Šesták. 1985. Gas exchange and dry matter accumulation during leaf development, p. 157-216. In: Šesták, Z. (ed.). Photosynthesis during leaf development. Springer, Berlin, Germany.

White, P.J. and M.R. Broadley. 2001. Chloride in soils and its uptake and movement within the plant: A review. Ann. Bot. (Lond.) 88:967-988.

Winsor, G.M. and D.M. Massey. 1958. The composition of tomato fruit. J. Sci. Food Agr. 9: 493-498.

Xu, H.L., L. Gauthier, and A. Gosselin. 1995. Stomatal and cuticular transpiration of greenhouse tomato plants in response to high solution electrical conductivity and low soil water content. J. Amer. Soc. Hort. Sci. 120:417422 